Yu. Yu. Serdiukova, S. G. Leonova, Yu. S. Kolisnyk

National University of Pharmacy

\title{
Development of a novel kinetic spectrophotometric method for the quantitative determination of Cefuroxime using Caro's acid
}

Development of new simple and economically profitable methods for the quantitative determination of Cefuroxime substance is of a great interest.

Aim. To study the reaction of Cefuroxime with Caro's acid and develop a new method for the quantitative determination of Cefuroxime based on the product of S-oxidation and perhydrolysis.

Materials and methods. To determine Cefuroxime substance the triple potassium salt of Caro's acid was used as an oxidizing agent. The procedure was developed as a kinetic spectrophotometric method.

Results and discussion. The initial rate method can be easily applied to determine Cefuroxime substance. The data obtained showed good results in accuracy, precision, LOQ and LOD. The RSD for the substance was 1.53-2.35 \%, $\delta=0.55-1.40 \%$. The direct linear dependence was observed in a wide range of concentrations $1-7 \mu \mathrm{g} \cdot \mathrm{mL}^{-1}$.

Conclusions. The possibility of Cefuroxime analytical determination by the biologically active part of the molecule, reproducible results and accuracy are the advantages of the method proposed. The data obtained are in good agreement with the standard pharmacopoeial HPLC method.

Key words: Cefuroxime; kinetic spectrophotometric method; quantitative determination; Caro's acid

Ю. Ю. Сердюкова, С. Г. Леонова, Ю. С. Колісник

\section{Розробка нової кінетико-спектрофоотометричної методики кількісного} визначення цефуроксиму за допомогою кислоти Каро

Розробка нових простих і економічно вигідних методик кількісного визначення цефуроксиму субстанції становить великий інтерес.

Мета даної роботи полягає у вивченні реакції цефуроксиму з кислотою Каро та у розробці нової методики кількісного визначення цефуроксиму за продуктом S-окиснення та пергідролізу.

Матеріали та методи. Потрійна калієва сіль кислоти Каро була використана як окисник для визначення субстанції цефуроксиму. Методика розроблена у кінетико-спектрофотометричному варіанті.

Результати та їх обговорення. Метод початкової швидкості може бути застосований для визначення цефуроксиму субстанції. Отримані добрі результати точності, відтворюваності, LOQ та LOD. RSD для субстанції становить 1,53-2,35 \%, $\delta$ = 0,55-1,40 \%. Пряма лінійна залежність спостерігається у широкому діапазоні концентрацій 1-7 мкг/мл.

Висновки. Можливість аналітичного визначення цефуроксиму за біологічно активною частиною молекули, відтворюваність і точність $є$ перевагами запропонованої методики. Отримані дані добре узгоджуються зі стандартною фармакопейною ВЕРХ методикою.

Ключові слова: цефуроксим; кінетико-спектрофотометричний метод; кількісне визначення; кислота Каро

Ю. Ю. Сердюкова, С. Г. Леонова, Ю. С. Колесник

\section{Разработка новой кинетико-спектрофотометрической методики количественного определения цефуроксима с помощью кислоты Каро}

Разработка новых простых и экономически выгодных методик количественного определения цефуроксима субстанции представляет большой интерес.

Цель данной работы заключается в изучении реакции цефуроксима с кислотой Каро и в разработке новой методики количественного определения цефуроксима, основанной на продукте S-окисления и пергидролиза.

Материалы и методы. Тройная калиевая соль кислоты Каро была использована в качестве окислителя для определения субстанции цефуроксима. Методика была разработана в кинетико-спектрофотометрическом варианте.

Результаты и их обсуждение. Метод начальной скорости может быть применен для определения цефуроксима субстанции. Получены хорошие результаты точности, воспроизводимости, LOQ и LOD. RSD для субстанции составляет 1,53-2,35 \%, $\delta=0,55-1,40 \%$. Прямая линейная зависимость наблюдается в широком диапазоне концентраций 1-7 мкг / мл.

Выводы. Возможность аналитического определения цефуроксима по биологически активной части молекулы, воспроизводимость и точность являются преимуществами предлагаемой методики. Полученные данные хорошо согласуются со стандартной фрармакопейной ВЭЖХ методикой.

Ключевые слова: цефуроксим; кинетико-спектрофотометрический метод; количественное определение; кислота Каро 
The quantitative determination of drugs becomes more and more important. The control of the quality and quantity is one of the obligatory steps of drug production. Therefore, development of new simple and economically profitable methods is of a great interest. The methods for the quantitative determination of Cefuroxime are different.

Classical iodometric method is provided for the assay of most of the pharmacopeial $\beta$-lactams, for which iodometric titration is particularly suitable $[1,2]$. The iodometric method is insensitive as all antibiotics, the initial substances for their production, as well as their degradation products, are oxidized by iodine. It is therefore not suitable for the purity control of antibiotics of this group [3]. Usually titration is a rapid and easy procedure, but unlikely to this, iodometric titration of cephalosporins is a long-lasting procedure (approximately $40 \mathrm{~min}$ ) [4]. The intensive literature review has found the application of methods of chromatography $[5,6]$, spectrophotometry [7-9], voltammetry [10], oxidimetry [11], spectrofluorimetry [12], chemiluminescence [13]. The SPhU and BrPh describe HPLC for the cephalosporin determination, which is surely the best method, but has a longtime preparation, expensive and complicated in performance. The kinetic spectrophotometric method belongs to modern and prospective ones. It can be applied by using a proper oxidation analytical reagent that should meet all requirements to analytical reagents. Potassium Caroate $\left(\mathrm{KHSO}_{5}\right)$ refers to such reagents. Its powder is commercially available and stable in the form of solution used in the experiment.

The aim of this work is to study the reaction of $\mathrm{Ce}$ furoxime with Caro's acid and develop a kinetic spectrophotometric method for the quantitative determination of Cefuroxime based on the product of S-oxidation and perhydrolysis. The possibilities of determination and peculiarities of the reaction of S-oxidation and perhydrolysis of Cefuroxime using potassium caroate as an analytical reagent were studied. The optimal conditions were determined, and the method was statistically checked.

\section{Materials and methods}

All materials were of an analytical reagent grade, and the solutions were prepared with double-distilled water.

The triple potassium salt of Caro's acid was used as an oxidizing agent, $2 \mathrm{KHSO}_{5} \cdot \mathrm{KHSO}_{4} \cdot \mathrm{K}_{2} \mathrm{SO}_{4}$ (the commercial name - Oxon ${ }^{\circledR}$ manufactured by DuPont). The active substance is potassium hydrogenperoxomonosulfate, $\mathrm{KHSO}_{5}$. The choice of the reagent was determined by its rather high oxidative activity, $\mathrm{E}_{0}=1.84 \mathrm{~V}$, availability, and satisfactory solubility in water.

\section{Preparation of standard solutions}

Preparation of $0.02 \mathrm{~mol} \mathrm{~L}^{-1}$ solution of potassium caroate. Dissolve $0.615 \mathrm{~g}$ of $2 \mathrm{KHSO}_{5} \bullet \mathrm{KHSO}_{4} \bullet \mathrm{K}_{2} \mathrm{SO}_{4}$, in a $100 \mathrm{~mL}$ volumetric flask in double-distilled water. Check the concentration of potassium caroate by iodometric titration.

Prepare sodium hydroxide $0.51 \mathrm{M}$ by dissolving $2 \mathrm{~g}$ in $100 \mathrm{~mL}$ of double-distilled water.

The study of S-oxidation reaction kinetics. Transfer $10.0 \mathrm{~mL}$ of $0.02 \mathrm{~mol} \mathrm{~L}^{-1}$ potassium hydrogenperoxo- monosulfate solution into a $100 \mathrm{~mL}$ volumetric flask, add $10.0 \mathrm{~mL}$ of $0.01 \mathrm{~mol} \mathrm{~L}^{-1}$ Cefuroxime solution, and switch a stopwatch on. Dilute to the volume and mix. Further transfer $10 \mathrm{~mL}$ of the mixture obtained into a titration flask using a pipette, add $1 \mathrm{~mL}$ of $0.1 \mathrm{~mol} \mathrm{~L}^{-1}$ sulfuric acid solution and $1 \mathrm{~mL}$ of $5 \%$ potassium iodine solution. Titrate the isolated iodine by $0.02 \mathrm{~mol} \mathrm{~L}^{-1} \mathrm{so}-$ lution of sodium thiosulfate in the presence of starch.

The pure substance of Cefuroxime was used.

A SF-46 spectrophotometer (LOMO) with $1 \mathrm{~cm}$ match quartz cells was used for spectral measurement.

\section{Results and discussion}

The peroxiacidic method proposed is based on the reaction of Cefuroxime oxidation by the excess of $\mathrm{KHSO}_{5}$ with the quantitative formation of the corresponding S-oxide in the acidic medium. The $\mathrm{KHSO}_{5}$ excess was determined by the method of iodometric titration.

The method proposed is based on the quantitative determination of Cefuroxime substance by the product of two conjugate reactions of peroxoacidic oxidation and perhydrolysis in the basic medium using Caro's acid as an analytical reagent $\left(\mathrm{KHSO}_{5}\right)$. The reaction mechanism has been proposed on the basis of the literature review and the experimental study as shown in Fig. 1.

The redox interaction between Cefuroxime and potassium peroxomonosulfate in the acidic medium $(\mathrm{pH}=3-5)$ was stoichiometrical and fast: $1 \mathrm{~mol}$ of Cefuroxime per $1 \mathrm{~mol}$ of $\mathrm{KHSO}_{5}$ (the observation time - $1 \mathrm{~min}$ ) was determined by the iodometric method.

In the basic medium Cefuroxime S-oxide undergoes hydrolytic cleavage. Fig. 2 shows the electronic spectra of Cefuroxime and the reaction product. The appearance of a new band with absorption $\lambda_{\max }=290 \mathrm{~nm}$ demonstrates its formation in the reaction of alkaline hydrolysis of Cefuroxime S-oxide in the presence of potassium peroxomonosulfate (the perhydrolysis reaction).

The appearance of a new band gave the possibility of development of a new method for the quantitative determination of Cefuroxime. To solve this problem the optimal conditions should be determined.

The absorbance changed substantially with the increase of the concentration of Caro's acid. The maximum tangent of inclination was obtained when $2.0 \mathrm{~mL}$ of $0.02 \mathrm{M}$ of Caro's acid was used. The maximum slope was obtained when $2 \mathrm{~mL}$ of $1.00 \mathrm{M} \mathrm{NaOH}$ was used. Over this volume no change in absorbance could be detected. Therefore, $2 \mathrm{~mL}$ of $1.00 \mathrm{M}$ of $\mathrm{NaOH}$ was used as an optimum value.

\section{The effect of the Cefuroxime concentration}

Pipette $1 \mathrm{~mL}, 3 \mathrm{~mL}, 4 \mathrm{~mL}, 5 \mathrm{~mL}, 6 \mathrm{~mL}, 7 \mathrm{~mL}$ of $1 \cdot 10^{-3} \mathrm{~mol} \mathrm{~L}^{-1}$ solution of Cefuroxime into $100 \mathrm{~mL}$ volumetric flasks containing $2 \mathrm{~mL}$ of $0.02 \mathrm{~mol} \mathrm{~L}^{-1} \mathrm{KHSO}_{5}$ solution and $2 \mathrm{~mL}$ of $1.00 \mathrm{~mol} \mathrm{~L}^{-1} \mathrm{NaOH}$ solution. Mix the content of the mixture of each flask well and record the increase in absorbance at $290 \mathrm{~nm}$ as a function of time for $15 \mathrm{~min}$ against the reagent blank (Fig. 3). It shows the dependence of absorption of Cefuroxime alkaline solutions on time at $290 \mathrm{~nm}$ and the acid concentration. They have linear dependence for the first 10-15 min. The corresponding plot is given in Fig. 3. 
<smiles>[R]NC1C(=O)N2C(C(=O)O)=C([R])CSC12</smiles><smiles>[R]N[C@H]1C(=O)N2C(C(=O)O)=C([R7])C[S@](=O)[C@H]12</smiles><smiles>[R]NC(C(=O)[O-])C(N=C([O+])C(=O)[O-])N=S(=O)=O</smiles><smiles>[R]NC(C=[N+]C([O+])=C([R])CS(=O)(=O)[O-])C(=O)[O-]</smiles>

$$
\lambda=290 \mathrm{~nm}
$$

$\mathrm{R}^{\prime \prime}=$<smiles>COC(N)=O</smiles>

Fig. 1. The scheme of chemical transformations of Cefuroxime using Caro's acid

As it is seen from the plot, the tangent of inclination depends on the Cefuroxime concentration. The kinetic curves show that the slope increases proportionally with the increase of the Cefuroxime concentration. Thus, the initial rate method can be successfully applied for determination of the content of Cefuroxime substance in the conjugated reaction between Cefuroxime and Caro's acid in the alkaline medium using the kinetic spectrophotometric method.

The validity of the method proposed was studied by performing recovery studies. Precision and accuracy were studied by analyzing five replicates of the sample solutions at three concentration levels. The relative standard deviations calculated were all below $2.2 \%$, indicating the excellent precision of the method proposed.

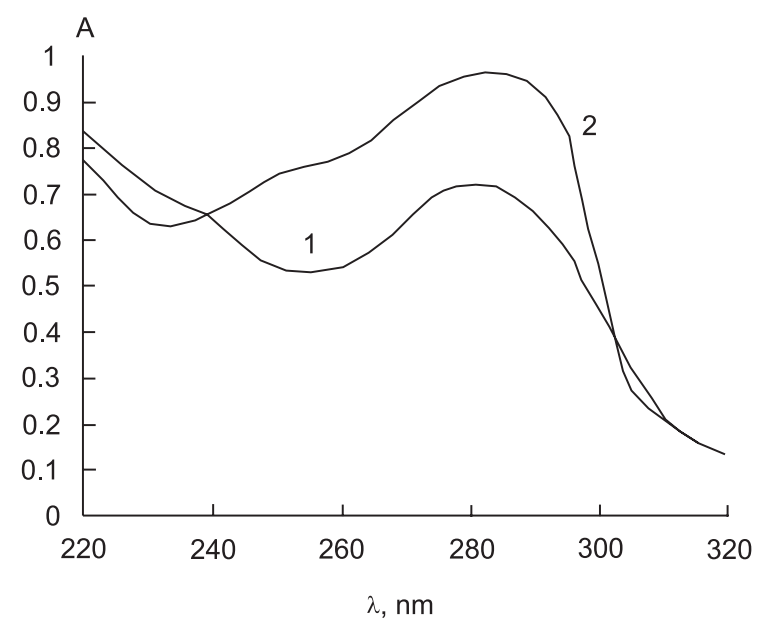

Fig. 2. Electronic spectra of Cefurixime absorption (1) and the product of conjugated reactions of S-oxidation and perhydrolysis with Caro's acid (2). $C$ (Cefuroxime) $=5 \times 10^{-3} \mathrm{~mol} \mathrm{~L}^{-1}$; $c\left(\mathrm{KHSO}_{5}\right)=4 \times 10^{-4} \mathrm{~mol} \mathrm{L-1} ; c(\mathrm{NaOH})=0.02 \mathrm{~mol} \mathrm{~L}^{-1}$
The procedure is as follows: place $0.42 \mathrm{~g}$ (accurate weight) of Cefuroxime in a $100 \mathrm{~mL}$ volumetric flask, dilute to the volume with double-distilled water. Further dilute $1 \mathrm{~mL}$ of this solution to the volume of $100 \mathrm{~mL}$ with double-distilled water at $20^{\circ} \mathrm{C}$. Transfer $10.00 \mathrm{~mL}$ of the solution obtained into a $100 \mathrm{~mL}$ volumetric flask containing $2 \mathrm{~mL}$ of $0.02 \mathrm{~mol} \mathrm{~L}^{-1} \mathrm{KHSO}_{5}$ solution and $2 \mathrm{~mL}$ of $1.00 \mathrm{~mol} \mathrm{~L}^{-1} \mathrm{NaOH}$ solution. Shake the content, and finally, dilute to the volume with double-distilled water. After addition of $\mathrm{NaOH}$ solution switch a stopwatch on. Transfer the solution obtained to a $1 \mathrm{~cm}$ cell to measure the absorbance at the wavelength of $290 \mathrm{~nm}$ for first the 15 min every 2 min against water.

The kinetic dependence curve of absorbance A on time (min) was obtained. The calculation was performed

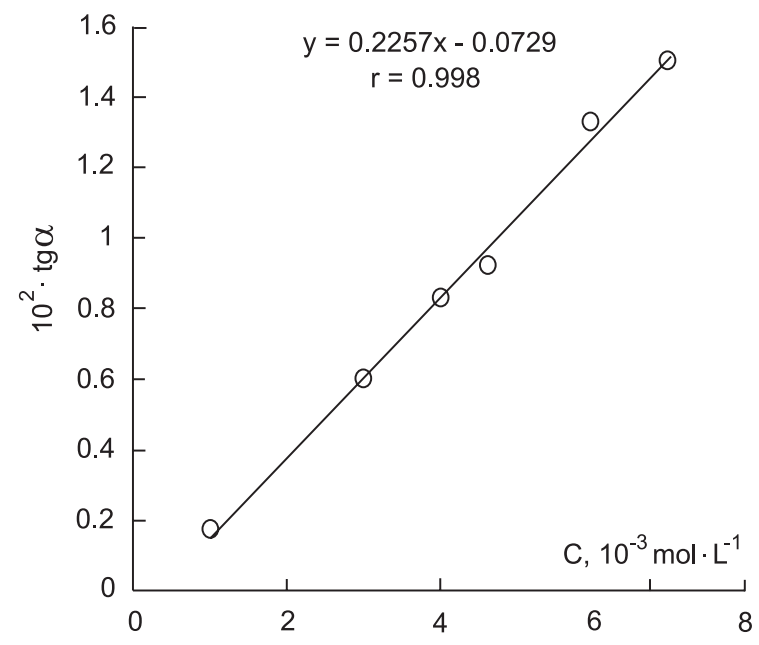

Fig. 3. The calibration plot for the kinetic determination of Cefuroxime pure substance. $c\left(\mathrm{KHSO}_{5}\right)=4 \cdot 10^{-4} \mathrm{~mol} \mathrm{~L}^{-1}$. $c(\mathrm{NaOH})=2.00 \cdot 10^{-2} \mathrm{~mol} \mathrm{~L}^{-1}$ 
Table bel claim was determined. The results of calculations

The results of calculations of Cefuroxime accuracy and precision

\begin{tabular}{|c|c|c|c|c|c|}
\hline $\begin{array}{c}\text { Added, } \\
\mathrm{mol} \mathrm{L}^{-1} 10^{3}\end{array}$ & $\begin{array}{c}\text { Found, } \\
\mathrm{mol} \mathrm{L}^{-1} 10^{3}\end{array}$ & $\begin{array}{c}\text { Mean, } \\
\mathrm{mol} \mathrm{L}^{-1} 10^{3}\end{array}$ & $\begin{array}{c}\text { Recovery, } \\
\%\end{array}$ & $\begin{array}{c}\text { RSD, } \\
\%\end{array}$ & $\delta, \%$ \\
\hline \multirow{5}{*}{3.00} & 2.98 & \multirow{5}{*}{3.03} & \multirow{5}{*}{101.00} & \multirow{5}{*}{2.35} & \multirow{5}{*}{1.0} \\
\hline & 2.98 & & & & \\
\hline & 2.98 & & & & \\
\hline & 3.11 & & & & \\
\hline & 3.11 & & & & \\
\hline \multirow{5}{*}{5.00} & 5.15 & \multirow{5}{*}{5.07} & \multirow{5}{*}{101.40} & \multirow{5}{*}{2.05} & \multirow{5}{*}{1.4} \\
\hline & 4.96 & & & & \\
\hline & 4.96 & & & & \\
\hline & 5.15 & & & & \\
\hline & 5.15 & & & & \\
\hline \multirow{5}{*}{7.00} & 6.97 & \multirow{5}{*}{7.04} & \multirow{5}{*}{100.55} & \multirow{5}{*}{1.53} & \multirow{5}{*}{0.55} \\
\hline & 6.97 & & & & \\
\hline & 7.10 & & & & \\
\hline & 7.19 & & & & \\
\hline & 6.97 & & & & \\
\hline
\end{tabular}

using the initial rate method (a differential variant). Five replicate estimations were done in a similar way. The content of Cefuroxime capsules was calculated, and la- are given in Table.

The LOD and LOQ were calculated based on the standard deviation of response and the slope of the calibration curve. It is expressed as $\mathrm{LOD}=3 \times \mathrm{S}_{\mathrm{a}} / \mathrm{b}, \mathrm{LOQ}=10 \times \mathrm{S}_{\mathrm{a}} / \mathrm{b}$ where $S_{a}$ is the standard deviation of response, $b$ is the slope of the calibration curve.

$\mathrm{LOD}=0.38 \mu \mathrm{g} / \mathrm{mL}, \mathrm{LOQ}=1.2 \mu \mathrm{g} / \mathrm{mL}$.

\section{CONCLUSIONS}

1. The possibility of the Cefuroxime analytical determination by the biologically active part of the molecule (alicyclic sulfur and $\beta$-lactam ring), reproducible results and accuracy are the advantages of the method proposed.

2 . The initial rate method can be easily applied to determine Cefuroxime substance, providing advantages during the experiment.

3 . The method developed has a good specificity and allows determining the content of the Cefuroxime main component avoiding impurities.

4. The results of accuracy and precision are in good agreement with the results obtained in the reference method. For the pure substance RSD $=1.53-2.35 \%$, $\delta=0.55-1.40 \%$. LOD $=0.38 \mu \mathrm{g} / \mathrm{mL}, \mathrm{LOQ}=1.2 \mu \mathrm{g} / \mathrm{mL}$.

Conflict of Interests: authors have no conflict of interests to declare.

\section{REFERENCES}

1. European Pharmacopoeia. - Strasbourg : Council of Europe. - 4 ed. - 2003. - P. 2975-2977.

2. British Pharmacopoeia. - London : The Stationery office, 2009. - 10952 p.

3. Gallo Martinez, L. Comparison of several methods used for the determination of cephalosporins. Analysis of cephalexin in pharmaceutical samples / L. Gallo Martinez, P. Campins Falco, A. Selivano Cabeza // J. of Pharmac. and Biomed. Analysis. - 2002. - Vol. 29, Issue 3. P. 405-423. doi: 10.1016/s0731-7085(02)00089-4

4. Фармацевтическая химия : учеб. пособие / ред. А. П. Арзамасцев. - М. : ГЭОТАР-МЕД, 2004. - 640 с.

5. Elias, B. Determination of Cefuroxime Axetil and Cefixime Trihydrate in Pharmaceutical Dosage Forms by RP-HPLC Method/ B. Elias, M. A. Alfeen // Pharmac. Analytical Chem. - 2016. - Vol. 2, Issue 2. - 5 p. doi: 10.4172/2471-2698.1000114

6. High performance liquid chromatographic method for the quantitative analysis of cefuroxime in pharmaceutical preparations / M. R. Siddiqui, Z. A. Alothman, S. M. Wabaidur et al. // J. of the Chilean Chem. Soc. - 2015. - Vol. 60, Issue 2. - P. 2869-2871. doi: 10.4067/ S0717-97072015000200001

7. Omar, M. A. Kinetic Spectrophotometric Determination of Certain Cephalosporins in Pharmaceutical Formulations / M. A. Omar, O. H. Abdelmageed, T. Z. Attia // Intern. J. of Analytical Chem. - 2009. - Vol. 2009. - P. 1 - 12. doi: 10.1155/2009/596379

8. Pritam, J. Development and validation of UV-Spectrophotometric method for determination of Cefuroxime Axetil in bulk and in Formulation / J. Pritam, P. Manish, S. Sanjay // Intern. J. of Drug Development \& Res. - 2011. - Vol. 3, Issue 4. - P. 318-322.

9. Rahman, Md R. Development and validation of UV spectrophotometric Methods for Determination of Cefuroxime in Pharmaceutical Dosage forms / Md. R. Rahman, Md. Asaduzzaman, S. M. Ashraful Islam // Am. J. of Pharmtech. Res. - 2012. - Vol. 2, Issue 4. - P. $351-358$.

10. Reddy, G. V. S. Estimation of cephalosporin antibiotics by differential pulse polarography / G. V. S. Reddy // Talanta. - 1997. - Vol. 44, Issue 4. - P. 627-631. doi: 10.1016/s0039-9140(96)02081-4

11. Serdiukova, Yu.Yu. Iodometric determination of cefuroxime by the potassium hydrogenperoxomonosulphate reaction / Yu. Yu. Serdiukova, М. M. Ivashura, T. O. Oleksienko // Вісник фармації. - 2016. - № 2 (86). - С. 6-8.

12. Omar, M. A. Kinetic spectrofluorimetric determination of certain cephalosporins in human plasma / M. A. Omar, O. H. Abdelmageed, T. Z. Attia // Talanta. - 2009. - Vol. 77, Issue 4. - P. 1394-1404. doi: 10.1016/j.talanta.2008.09.040

13. Niu, L. A study of the chemiluminescence behavior of cephalosporins with luminol and its analytical application / L. Niu, S. Zhenghua, H. Xili // National Library of Medicine. Drug Metabolism Lett. - 2009. - Vol. 3. - P. 144-151. doi: 10.2174/187231209789352157

\section{REFERENCES}

1. European Pharmacopoeia, 4 ed. (2003). Strasbourg : Council of Europe, 2975-2977.

2. British Pharmacopoeia. (2009). London : The Stationery office, 10952.

3. Gallo Martínez, L., Campíns Falcó, P., Sevillano Cabeza, A. (2002). Comparison of several methods used for the determination of cephalosporins. Analysis of cephalexin in pharmaceutical samples. Journal of Pharmaceutical and Biomedical Analysis, 29 (3), $405-423$. doi: 10.1016/s0731-7085(02)00089-4

4. Arzamastcev, A. P. (2004). Farmatcevticheskaia khimiia. Moscow: GEOTAR-MED, 640. 
5. Elias, B., Anas Alfeen, M. (2016). Determination of Cefuroxime Axetil and Cefixime Trihydrate in Pharmaceutical Dosage Forms by RP-HPLC Method. Pharmaceutical Analytical Chemistry, 2 (2), 5. doi: 10.4172/2471-2698.1000114

6. Siddiqui, M. R., Alothman, Z. A., Wabaidur, S. M. et. al. (2015). High performance liquid chromatographic method for the quantitative analysis of cefuroxime in pharmaceutical preparations. Journal of the Chilean Chemical Society, 60 (2), 2869-2871. doi: 10.4067/ s0717-97072015000200001

7. Omar, M. A., Abdelmageed, O. H., Attia, T. Z. (2009). Kinetic Spectrophotometric Determination of Certain Cephalosporins in Pharmaceutical Formulations. International Journal of Analytical Chemistry, 2009, 1-12. doi: 10.1155/2009/596379

8. Pritam, J., Manish, P., Sanjay, S. (2011). Development and validation of UV-Spectrophotometric method for determination of Cefuroxime Axetil in bulk and in Formulation. International Journal of Drug Development \& Research, 3 (4), 318-322.

9. Rahman, Md R., Asaduzzaman, Md., Ashraful Islam, S. M. (2012). Development and validation of UV spectrophotometric Methods for Determination of Cefuroxime in Pharmaceutical Dosage forms. American journal of pharmtech research, 2 (4), 351-358.

10. Reddy, G. (1997). Estimation of cephalosporin antibiotics by differential pulse polarography. Talanta, 44 (4), 627-631. doi: 10.1016/ s0039-9140(96)02081-4

11. Serdiukova, Yu. Yu., Ivashura, M. M., Oleksienko, T. O. (2016). Iodometric determination of cefuroxime by the potassium hydrogenperoxomonosulphate reaction. Visnik farmacï, 2 (86), 6-8.

12. Omar, M. A., Abdelmageed, O. H., Attia, T. Z. (2009). Kinetic spectrofluorimetric determination of certain cephalosporins in human plasma. Talanta, 77 (4), 1394-1404. doi: 10.1016/j.talanta.2008.09.040

13. Niu, L., Song, Z., He, X. (2009). A Study of the Chemiluminescence Behavior of Cephalosporins with Luminol and Its Analytical Application. Drug Metabolism Letters, 3 (3), 144-151. doi: 10.2174/187231209789352157

Information about authors:

Serdiukova Yu. Yu., Candidate of Pharmacy (Ph. D.), teaching assistant of the Department of Physical and Colloid Chemistry, National University of Pharmacy.

E-mail: tamadiw@gmail.com. ORCID - http://orcid.org/0000-0002-4755-3660

Leonova S. G., Candidate of Pharmacy (Ph. D.), associate professor of the Pharmaceutical Chemistry Department, National University of Pharmacy

Kolisnyk Yu. S., Candidate of Pharmacy (Ph. D.), teaching assistant of the Department of Analytical Chemistry, National University of Pharmacy

Відомості про авторів:

Сердюкова Ю. Ю., канд. фарм. наук, асистент кафедри фізичної та колоїдної хімії, Національний фармацевтичний університет.

E-mail: tamadiw@gmail.com. ORCID - http://orcid.org/0000-0002-4755-3660

Леонова С. Г., канд. фарм. наук, доцент кафедри фармацевтичної хімії, Національний фармацевтичний університет

Колісник Ю. С., канд. фарм. наук, асистент кафедри аналітичної хімії, Національний фармацевтичний університет

Сведения об авторах:

Сердюкова Ю. Ю., канд. фарм. наук, ассистент кафедры физической и коллоидной химии, Национальный фармацевтический университет.

E-mail: tamadiw@gmail.com. ORCID - http://orcid.org/0000-0002-4755-3660

Леонова С. Г., канд. фарм. наук, доцент кафедры фармацевтической химии, Национальный фармацевтический университет

Колесник Ю. С., канд. фарм. наук, ассистент кафедры аналитической химии, Национальный фармацевтический университет 